\title{
Characterization of food web structure of the upper continental slope of the Celtic Sea highlighting the trophic ecology of five deep-sea fishes
}

\author{
Kopp Dorothee ${ }^{1,{ }^{*}}$, Robert Marianne ${ }^{1}$, Pawlowski Lionel ${ }^{1}$ \\ ${ }^{1}$ Unité de Sciences et Technologies halieutiques; Laboratoire de Technologie et Biologie Halieutique; \\ Ifremer; Lorient ,France \\ * Corresponding author : Dorothee Kopp, email address : dorothee.kopp@ifremer.fr
}

\begin{abstract}
:
In marine ecosystems, the study of trophic relationships has extensively benefited from the development of stable isotope analyses (SIA) as dietary tracers. SIA are particularly useful in elucidating the structure of deep sea food webs given the constraints involved in obtaining gut-content data from deep trawling. We used carbon and nitrogen stable isotope analyses and Stable Isotope Bayesian Ellipses in R (SIBER) and Stable Isotope Analysis in R (SIAR) routines, to determine the trophic ecology of five deep-sea fishes from the upper continental slope of the Celtic Sea. SIA made it possible to deduce some general tendencies in food-web structure and species trophic interactions and confirmed diet determined by gut-content analysis for the same species, in other ecoregions. More specifically, mixing models revealed that the deep sea species considered are omnivorous and are able to feed on all the sampled taxa. Based on isotopic ratio, no clear differences in fish diet could be detected from one species to another except for rabbit fish, which has benthic affinities. Three species, blackbelly rosefish, greater forkbeard and softhead grenadier showed overlapping isotopic niches. This study is the first attempt to describe the trophic ecology of deep sea species on the Celtic Sea upper continental slope. In the context of the development of ecosystem integrated modeling approaches for managing fisheries in the Celtic sea, and considering the vulnerability of deep-water species, improving the knowledge on the trophic ecology of these local species is of importance in order to allow their sustainable exploitation.
\end{abstract}

\section{Acknowledgments}

The work was part of the EATME project supported by France Filière Pêche and Région Bretagne. The authors thank G. Allanic and M. Denamiel for their help onboard the R/V Thalassa and at the laboratory. 
Introduction

While fish stocks of the continental shelf are widely exploited and have become depleted, deep-water fisheries (DWFs) have been considered as alternative resources for fishermen since the beginning of the 1970s (Large et al., 2013). However, due to a lack of information on stock status and fisheries production potential, rapid signs of decline of deep-water stocks have raised concerns about management of deep-water fisheries and conservation of the species and their ecosystems (Large et al., 2002; Bailey et al., 2009).

Despite this analysis, the biology of deep-sea species remains poorly known compared with the information available on demersal fish species of the continental shelf. This is mainly related to the technical challenges of studying these species. Traditional techniques for studying food web interactions are difficult to implement for deep-sea species. Stomach content analyses are limited by potential regurgitation due to pressure effects, and in situ observations using video are constrained by restricted accessibility of deep-sea areas. Moreover, many deep-water species have biological features adapted to the characteristics of the deep-water environment e.g. slow growth, long life spans, late sexual maturity and intermittent spawning, that may not occur every year (FAO, 2009; Large et al. , 2013) in conjunction to other features for some species such as migration patterns or depth ranges varying with ages. The restrained access to deep-sea areas complicates both data collection and accurate tracking of the population cohorts resulting in poor, when possible, biological parameter estimation on many deep-sea fishes. Therefore, many common parameters in fish biology such as life span are still poorly known or have remained hypothetical until now.

One way to study fish biology is to understand their ecological niche, in which one component is trophic niche. In recent decades, increasing access of stable isotope analysis (SIA) has facilitated trophic niche study compared with former more arduous tools such as stomach content analysis. Indeed, stable isotopes provide a powerful integrative measure of trophic niche and have several advantages: they constitute a single diversity scale common to all species, they provide 
temporal integration of dietary information, isotopic signature acquisition is easy and fast, and the tool allows comparisons among populations (Bearhop et al., 2004). Several previous papers proposed to study trophic niche by describing the isotopic space occupied by a species, population or group of interest in a bivariate plan. Several metrics have been formulated from this approach, such as the total isotopic area or the $\delta^{13} \mathrm{C}$ and $\delta^{15} \mathrm{~N}$ ranges, which provide details about the breadth of the niche. Other metrics such as the distance to the centroid provide different information about the degree of trophic diversity within a group (Layman et al., 2007). Using these metrics, comparisons of isotopic niches among groups could be made to detect potential differences in trophic position or resource use (Turner et al., 2010). However, one of the drawbacks of Layman's metrics is that it is difficult or even misleading to use them to compare groups composed of small numbers of samples or samples of different sizes. This problem was solved by Jackson et al. (2011) who proposed to use multivariate ellipse-based metrics to define isotopic niche. These metrics are unbiased with respect to sample size and allow comparison of datasets of different sizes.

These definitions of the trophic niche provide information about food web structure and potential relationships between organisms by comparing trophic niche position and breadth among groups of individuals, but are not direct characterizations of trophic niche in the same sense as Newsome et al. (2007). These authors suggest that an alternative way to determine trophic niche is to transform isotopic values into dietary proportions. Several tools could be used for this purpose (see Layman et al., 2011 for a complete review concerning mixing models), including Bayesian stable isotope mixing models, which integrate the uncertainty of input parameters, such as sources and mixtures of isotopic values or fractionation values, to characterize the probability distributions of source contributions to a mixture (e.g. Parnell et al., 2010).

In this study we provide a first description of the food web of the upper part of the continental slope of the Celtic Sea. We used carbon and nitrogen stable isotope analyses to 
determine the trophic position of 33 species sampled during the French EVHOE survey (part of the International Bottom Trawl Survey). More interestingly, we focused on the trophic ecology of five species recognized as deep-sea fish, according to both the European regulation on deep-sea species (Council Regulation (EC) No 2347/2002) and the analysis of haul compositions for the deepest strata of the EVHOE survey in the Celtic Sea. Species diets and trophic niches were identified, compared and discussed.

Methods

Sample collection and stable isotope analysis (SIA)

Epifaunal invertebrates and fishes were sampled in the Celtic Sea during the EVHOE survey (part of the International Bottom Trawl Survey, ICES, 2015) in November 2014 using a GOV (Grande Ouverture Verticale) demersal trawl with a cod-end of $20 \mathrm{~mm}$ stretched mesh, towed for $30 \mathrm{~min}$ at a speed of approximately 3.5 knots by R/V "Thalassa". All fishing operations were carried out during the daytime. As our samples were collected by bottom trawling, small epifauna was underrepresented in the samples and infauna was practically absent. All samples were kept frozen until processing in the laboratory. Deep-water samples were collected on two sites on the continental slope with depths of 415 and 516 meters (Fig. 1).

153 samples corresponding to 33 species were analyzed for stable isotopes of carbon and nitrogen to examine food web structure and consumer trophic ecology. $\delta^{15} \mathrm{~N}$ values were used to define the trophic level of consumers, and $\delta^{13} \mathrm{C}$ values were used to identify their position relative to pelagic or benthic trophic pathways (De Niro \& Epstein, 1978). Tissues were prepared for SIA as follows. For invertebrates, processing varied according to taxon: for shrimps, muscle samples were taken from the abdomen; for bivalve mollusks, a sample was taken of the adductor muscle; for gasteropod mollusks, a sample was taken from the foot; for cephalopods, a mantle tissue sample was taken; and 
for sea urchins, the gonads were used. For fishes, a sample of white dorsal muscle was dissected. After dissection, tissue samples of all benthic taxa were washed with distilled water in order to prevent any contamination by sediment carbonates. All samples were oven dried $\left(60^{\circ} \mathrm{C}\right.$ for $\left.48 \mathrm{~h}\right)$ and ground into a homogeneous powder using a mixer mill. Determination of $\delta^{15} \mathrm{~N}, \delta^{13} \mathrm{C}$ and $\%$ content of $\mathrm{C}$ and $\mathrm{N}$ was done at the Stable Isotopes in Nature Laboratory (University of New Brunswick, Canada) using a Carlo Erba NC2500 Elemental Analyzer. For all taxa except sea urchins, the mean observed C:N ratio was lower than 3.5, the value above which lipid normalization is recommended (Post et al., 2007). Normalization of $\delta^{13} \mathrm{C}$ ratios for urchins was performed according to the following equation (Post et al., 2007):

$\delta^{13} \mathrm{C}_{\text {normalized }}=\delta^{13} \mathrm{C}_{\text {untreated }}-3.32+0.99 \mathrm{C}: \mathrm{N}$

\section{Selection of deep-sea species}

Deep-sea species were selected according to the European regulation on the management of deepwater fisheries (EC) No 2347/2002 (EC, 2002) and on the historical time series of the catch sampled in the Celtic Sea during the EVHOE survey. Depth and catch data were available from the historical database of the EVHOE survey covering the years 1997 to 2014. Data were geographically limited to above $48^{\circ} \mathrm{N}$ of latitude, which is the usual agreed boundary between the Bay of Biscay and the Celtic Sea (Fig. 1). From this data, and following FAO and EU regulations, eight fish species collected could be considered as deep water species: alfonsino Beryx spp., velvet belly Etmopterus spinax, blackmouth catshark Galeus melastomus, greater forkbeard Phycis blennoides, rabbit fish Chimaera monstrosa, blackbelly rosefish Helicolenus dactylopterus, softhead grenadier Malacocephalus laevis, and hollowsnout grenadier Coelorinchus caelorhincus. 


\section{Data analysis}

\section{Description of fish diet}

Although the most recent mixing models allow the inclusion of numerous sources, the inherent complexity of natural systems and the multiplicity of potential food sources often requires merging of isotopically similar sources (Phillips et al., 2005) in order to reduce the number of sources and provide more realistic solutions.

For this purpose, trophic groups of potential prey were identified by hierarchical clustering analysis on $\delta^{15} \mathrm{~N}$ and $\delta^{13} \mathrm{C}$ values. Based on the trophic enrichment from a prey to its predator, all species with a trophic level inferior to the species of interest were considered as potential prey. Ward's minimum variance method (Ward, 1963) was used, which is based on the linear model criterion of least squares and has the objective of defining groups that minimize the within-group sums of squares. Computation of within-group sums of squares were based on a Euclidean model. The optimal number of clusters was assessed by visual inspection of the resulting dendrogram and confirmed using graphs of the fusion level (Borcard et al., 2011).

The Bayesian mixing model SIAR (Stable Isotope Analysis in R, Parnell et al., 2010) was used to determine the contribution of the groups of potential prey to deep-sea fish diets. SIAR is a mixing model that takes into account the variability of input parameters like consumer and source isotopic signatures and trophic enrichment factor. Fractionation factors between resources and consumers were assumed to be $1 \pm 0.5$ for $\delta^{13} \mathrm{C}$ and $3.4 \pm 1$ for $\delta^{15} \mathrm{~N}$, values, which fall within the range most often reported for consumers analyzed based on muscle. 
Isotopic niche

Isotopic niche areas and overlapping among deep-sea fish were determined using Stable Isotope Bayesian Ellipses (SIBER) incorporated in the SIAR library (Jackson et al., 2011). These isotopic niches could be used as proxies of trophic diversity and constitute quantitative indications of niche space. Among the several metrics available in the SIBER routine, we selected the corrected Standard Ellipse Area (SEAc) that accounts for small sampling sizes. The calculation of SEAc made it possible to determine isotopic niche overlap, which was then used to describe dietary similarity among species.

Following Turner et al. (2010) we tested whether the centroids of the isotopic niches occupied different locations in bivariate space, i.e. whether the Euclidean distance between them was significantly different from zero. Residual permutation procedure and multivariate Hotelling's $\mathrm{T}^{2}$ test statistic were used to test for significant differences in centroid location. Script and complete discussion about these statistics can be found in Turner et al. (2010).

All the statistical analyses were performed using R software version 3.1.3 ( $R$ Development Core Team, 2015).

Results

Food web structure

Thirty-three species were analyzed for stable isotopic ratios. Organisms in the upper slope of the Celtic Sea presented $\delta^{15} \mathrm{~N}$ values ranging from $6.2 \%$ for bivalve mollusc Pseudamussium peslutrae to 13.8\% for John dory Zeus faber (Table I). $\delta^{13} \mathrm{C}$ values ranged from $-19.5 \%$ o for cephalopod Illex coindetii to $-17 \%$ for crustaceans Nephrops norvegicus and Polycheles typhlops (Fig. 2; Table I).

The overall correlation between $\delta^{13} \mathrm{C}$ and $\delta^{15} \mathrm{~N}$ values was weak $\left(r^{2}=7.71 .10^{-4}, n=34, \delta^{15} \mathrm{~N}=0.0632\right.$ $\delta^{13} \mathrm{C}+11.27, \mathrm{p}=0.88$; Fig. 2) indicating a non-linear food web structure and providing evidence for 
multiple trophic pathways in the upper slope from the Celtic Sea. The position of $P$. peslutrae in the food web indicates a benthic pathway supplying benthic suspension feeders. Depleted $\delta^{13} \mathrm{C}$ values of plankton feeder fishes such as blue whiting Micromesistius poutassou may indicate a pelagic pathway rooted in particulate organic matter on which zooplankton depends.

Prey contributions to the diet of deep-sea species

Based on hierarchical clustering performed on $\delta^{13} \mathrm{C}$ and $\delta^{15} \mathrm{~N}$ values, five groups of potential prey were identified (Fig. 2). Two groups of tertiary consumers could be distinguished: a pelagic one (Group 1), represented by hake and cephalopods, and another (Group 2) that was composed of Molva macrophthalma and argentine Argentina sphyraena (Fig. 2). Isotopic values allowed further discrimination of two groups of secondary consumers: one formed by benthic species such as flatfish and Nephrops (Group 3) and one located at the interface between the pelagic and benthic pathways (Group 4; Fig. 2). Finally, Group 5 corresponded to the suspension feeding bivalve $P$. peslutrae.

The Bayesian mixing models revealed that all deep-sea species considered are omnivorous and able to feed on all the sampled taxa (Fig. 3). No clear differences could be detected from one species to another. The main contributors to the diet of four deep-sea fishes are the group composed of $P$. peslutrae (Gr. 5) and the group of mixed species (Gr. 4 on Fig. 2). Only for C. monstrosa, is Gr. 3, composed of species with benthic affinities, the major contributor (Fig. 3). As only one isotopic value was available for each of the species Etmopterus spinax and Galeus melastomus, their diet could not be assessed using SIAR. Additionally, no prey with lower TL than Beryx spp. were sampled, so the diet of this species could not be determined.

Niche breadth and overlap

Using the individual $\delta^{13} \mathrm{C}$ and $\delta^{15} \mathrm{~N}$ data on a bi-plot, it appears that three species have substantial niche overlaps. Helicolenus dactylopterus shows a large overlap of its isotopic niche with Phycis 
blennoides $\left(0.11 \% \mathrm{o}^{2}\right)$ (Fig. 4), which occupies $44 \%$ and $34 \%$ of their total niche areas, respectively. Isotopic niche positions revealed that these two species centroids occupied the same location in the bivariate space (distance $=0.24, P=0.33$; Hotelling's $\mathrm{T}^{2}=3.22, P=0.26$ ). In a more limited way, Helicolenus dactylopterus also overlaps with Malacocephalus laevis $\left(0.003 \%{ }^{2}\right)$ (Fig. 4), with an overlap area comprising $1 \%$ and $1.5 \%$ of their total niche areas, respectively, although their centroids are distinct (distance $=0.56, P=0.002 ;$ Hotelling's $\mathrm{T}^{2}=15.19, P=0.008$ ). Coelorinchus caelorhincus and Chimaera monstrosa had distinct isotopic niches and did not overlap with other species. In the same way as for SIAR calculation, the low number of samples for E. spinax, G. melastomus and Beryx spp. did not allow niche calculation for these species.

\section{Discussion}

This study provides new insights on the overall food web structure of the upper part of the continental slope and trophic ecology of five deepwater species.

Examination of the overall structure of Celtic Sea deep-sea food web revealed a compact structure with many fish species being isotopically close to benthic organisms, e.g. Beryx sp. and $C$. monstrosa, which have similar $\delta^{15} \mathrm{~N}$ than Buccinum humphreysianum or violet heart-urchin Spatangus purpureus. According to Dayton \& Hessler (1972), trophic levels in the deep-waters are almost completely merged because the larger the organism, the more it will have to search to obtain sufficient food and the more likely it will be to prey on organisms further down the food chain.

A review of trophic ecology research done on deep-sea fish species confirmed this global trend and revealed that studies on resources use and fish competition in the Celtic Sea are limited. Several studies using stomach content analysis have been made on the diet of the species considered in other European regions, e.g. Norwegian Sea (Du Buit, 1978), Mediterranean Sea (MacPherson, 1980; Consoli et al., 2010), Skagerrak in the North Sea (Bergstad et al., 2003), Portuguese coasts 
(Santos \& Borges, 2001; Neves et al., 2012) and worldwide, e.g. in the US (Goldman \& Sedberry, 2011) and New Zealand (Horn et al., 2010). Stomach content analysis from other regions support results obtained using stable isotopes in the Celtic Sea for the five species for which mixing models were used. Chimaera monstrosa is clearly identified as a benthic feeder (MacPherson, 1980; Mauchline \& Gordon, 1983; Santos \& Borges, 2001; Bergstad et al., 2003; Moura et al., 2005), as in the present study. The four other species present a bentho-pelagic diet with a large variety of ingested prey (Helicolenus dactylopterus: Du Buit, 1978; Consoli et al., 2010; Neves et al., 2012; Coelorinchus caelorhincus: Du Buit, 1978; Mauchline \& Gordon, 1984; Phycis blennoides: Du Buit, 1978; Morte et al., 2002; Malacocephalus laevis: Mauchline \& Gordon, 1984; Santos \& Borges, 2001). This omnivorous generalist behavior explains why the mixing models could not identify preferential food items in the fish diet but that all prey could be contributors. According to Dayton \& Hessler (1972), large mobile predators such as fish in the deep sea should be extreme food generalists capable of eating any prey that they encounter and catch. Indeed, in these environments where large food items are scarce, it is an advantage to be opportunistic rather than being specialized in order not to spend too much time searching for food.

Despite numerous technological developments of observing platforms, such as Remote Operated Vehicles or benthic cameras, deepwater species remain poorly known in terms of behavior, biology and trophic ecology. It is a concern for management as many deepwater species in Europe have been heavily exploited without any reliable information on fisheries production potentials (Large et al., 2002). Despite the implementation of EU regulation No 2347/2002 which has limited since 2003 deepwater fishing, the single-species approach in management of fish stocks has remained problematic in the Celtic sea for many deepwater species because 1) of the frequent lack of proper single-species assessment method; 2) of the mixed nature of the fisheries where any fishing tows will result in an assemblage of caught species under diverse and conflicting regulations and restrictions. The growing effort toward the development of ecosystem integrated management is expected to provide a more sustainable management by considering the interactions between 
species and environmental effects related to fisheries. However, any quantitative approach to modeling food webs currently involves many uncertainties, as parameters often have to be borrowed from the literature, from other areas, or from taxonomically close species. In this context, this study gathers valuable information for such a trophic modeling framework, especially a description of the local food web structure and detailed information on the trophic ecology of five deepwater species in the Celtic Sea. This may prove helpful to assess the magnitude of exploitation of those species, the side-effect of the fishing pressure over other commercial species they interact with and to propose alternate management scenarios. In light of research carried out on continental slope fisheries, operational multispecies assessment models may be the key to a more ecosystem-based approach to deepwater fisheries in the long term.

\section{References}

Bailey, D.M., Collins, M.A., Gordon, J.D.M., Zuur, A.F., Priede, I.G. (2009). Long-term changes in deepwater fish populations in the northeast Atlantic: a deeper reaching effect of fisheries? Proceedings of the Royal Society B, 276, 1965-1969. doi:10.1098/rspb.2009.0098

Bearhop, S., Adams, C.E., Waldron, S., Fuller, R.A., Macleod, H. (2004). Determining trophic niche width: a novel approach using stable isotope analysis. Journal of Animal Ecology, 73, 1007-1012. doi: 10.1111/j.0021-8790.2004.00861.x

Bergstad, O.A., Wik, Å.D., Hildre, $\varnothing$. (2003). Predator-prey relationships and food sources of the Skagerrak deep-water fish assemblage. Journal of the Northwest Atlantic Fishery Science, 31, $165-180$.

Borcard, D., Gillet, F., Legendre, P. (2011). Numerical Ecology with R. Use R! Series. Springer, New York, USA. 
Consoli, P., Battaglia, P., Castriota, L., Esposito, V., Romeo, T., Andaloro, F. (2010). Age, growth and feeding habits of the bluemouth rockfish, Helicolenus dactylopterus dactylopterus (Delaroche 1809) in the central Mediterranean (southern Tyrrhenian Sea). Journal of Applied Ichthyology, 26, 583-591. doi: 10.1111/j.1439-0426.2010.01467.x

Dayton, P.K. \& Hessler, R.R. (1972). Role of biological disturbance in maintaining diversity in the deep sea. Deep-Sea Research, 19, 199-208.

De Niro, M.J. \& Epstein, S. (1978). Influence of diet on distribution of carbon isotopes in animals. Geochimica et Cosmochimica Acta, 42, 495-506.

Du Buit, M.-H. (1978). Alimentation de quelques poissons téléostéens de profondeur dans la zone du seuil de Wyville Thomson. Oceanologica Acta, 1, 129-134.

EC (2002). Council Regulation (EC) No. 2347/2002-Establishing specific access requirements and associated conditions applicable to fishing for deep-sea stocks, 11. Official Journal of the European Union L 351.

FAO (2009). FAO international guidelines for the management of deep-sea fisheries in the high seas. Rome, 73pp.

Goldman, S.F. \& Sedberry, G.R. (2011). Feeding habits of some demersal fish on the Charleston Bump off the southeastern United States. ICES Journal of Marine Science, 68, 390-398. doi:https://doi.org/10.1093/icesjms/fsq064

Horn, P.L., Forman, J., Dunn, M.R. (2010). Feeding habits of alfonsino Beryx splendens. Journal of Fish Biology, 76, 2382-2400. doi: 10.1111/j.1095-8649.2010.02630.x

ICES (2015). Report of the International Bottom Trawl Survey Working Group (IBTSWG), 23-27 March 2015, Bergen, Norway. ICES CM 2015/SSGIEOM:24, 278 pp. 
Jackson, A.L., Inger, R., Parnell, A.C., Bearhop, S. (2011). Comparing isotopic niche widths among and within communities: SIBER - Stable Isotope Bayesian Ellipses in R. Journal of Animal Ecology, 80, 595-602. doi: 10.1111/j.1365-2656.2011.01806.x

Large, P.A., Hammer, C., Bergstad, O.A., Godon, J.D.M., Lorance, P. (2002). Deep-water fisheries of the northeast Atlantic: II assessment and management approaches. Journal of the Northwest Atlantic Fishery Science, 31, 151-163.

Large, P.A., Agnew, D.J., Álvarez Pérez, J.A., Barrio Froján, C., Cloete, R., Damalas, D., Dransfeld, L., Edwards, C.T.T., Feist, S., Figueiredo, I., González, F., Herrera, J.G., Kenny, A., Jakobsdóttir, K., Longshaw, M., Lorance, P., Marchal, P., Mytilineou, C., Planque, B., Politou, C.Y. (2013). Strengths and weaknesses of the management and monitoring of deep-water stocks, fisheries, and ecosystems in various areas of the world-A roadmap toward sustainable deep-water fisheries in the Northeast Atlantic? Reviews in Fisheries Science, 21, 157-180. doi: http://dx.doi.org/10.1080/10641262.2013.785475

Layman. C.A., Arrington, D.A., Montaña, C.G., Post, D.M. (2007). Can stable isotope ratios provide for community-wide measures of trophic structure? Ecology, 88, 42-48.

Layman, C.A., Araujo, M.S., Boucel, R., Hammerschlag-Peyer, C.M., Harrison, E., Jud, Z.R., Matich, P., Rosenblatt, E., Vaudo, J.J., Yeager, L.A., Post, D.M., Bearhop, S. (2011). Applying stable isotopes to examine food-web structure: an overview of analytical tools. Biological Reviews, $87,545-562$. doi: 10.1111/j.1469-185X.2011.00208.x

MacPherson, E. (1980). Food and feeding of Chimaera monstrosa, Linnaeus, 1758, in the western Mediterranean. Journal du Conseil International pour l'Exploration de la Mer, 39, 26-29. doi: https://doi.org/10.1093/icesjms/39.1.26

Mauchline, J. \& Gordon, J.D.M. (1983). Diets of the sharks and chimaeroids of the Rockall Trough, northeastern Atlantic Ocean. Marine Biology, 75, 269-278. doi: 10.1007/BF00406012 
Mauchline, J. \& Gordon, J.D.M. (1984). Diets and bathymetric distributions of the macrourid fish of the Rockall Trough, northeastern Atlantic Ocean. Marine Biology, 81, 107-121. doi:10.1007/BF00393109

Morte, M.S., Redón, M.J., Sanz-Brau, A. (2002). Diet of Phycis blennoides (Gadidae) in relation to fish size and season in the western Mediterranean (Spain). P.S.Z.N.: Marine Ecology, 23, 141-155.

Moura, T., Figueiredo, I., Bordalo-Machado, P., Serrano Gordo, L. (2005). Feeding habits of Chimaera monstrosa L. (Chimaeridae) in relation to its ontogenetic development on the southern Portuguese continental slope. Marine Biology Research, 1, 118-126. doi: http://dx.doi.org/10.1080/17451000510019079

Neves, A., Sequeira, V., Barros Paiva, R., Rita Vieira, A., Serrano Gordo, L. (2012). Feeding habits of the bluemouth, Helicolenus dactylopterus dactylopterus (Delaroche, 1809) (Pisces: Sebastidae) in the Portuguese coast. Helgoland Marine Research, 66, 189-197. doi: 10.1007/s10152-011$0260-5$

Newsome, S.D., Martinez del Rio, C., Bearhop, S., Phillips, D.L. (2007). A niche for isotopic ecology. Frontiers in Ecology and the Environment, 5, 429-436. doi: 10.1890/060150.1

Parnell, A.C., Inger, R., Bearhop, S., Jackson, A. (2010). Source partitioning using stable isotopes: coping with too much variation. PloS ONE, 5, e9672. doi: https://doi.org/10.1371/journal.pone.0009672

Phillips, D.L., Newsome, S.D., Gregg, J.W. (2005). Combining sources in stable isotope mixing models: alternative methods. Oecologia, 144, 520-527. doi: 10.1007/s00442-004-1816-8

Post, D.M., Layman, C.A., Arrington, D.A., Takimoto, G., Quattrochi, J., Montaña, C.G. (2007). Getting to the fat of the matter: models, methods and assumptions for dealing with lipids in stable isotope analyses. Oecologia, 152, 179-189. doi: 10.1007/s00442-006-0630-x 
R Development Core Team. (2015). R: A Language and Environment for Statistical Computing.R Foundation for Statistical Computing, Vienna, Austria, ISBN 3-900051-07-0. http://www.Rproject.org/.

Santos, J. \& Borges, T. (2001). Trophic relationships in deep-water fish communities off Algarve, Portugal. Fisheries Research, 51, 337-341. doi: http://doi.org/10.1016/S0165-7836(01)00257-0

Turner, T.F., Collyer, M.L., Krabbenhoft, T.J. (2010). A general hypothesis-testing framework for stable isotope ratios in ecological studies. Ecology, 91, 2227-2233. doi: 10.1890/09-1454.1

Ward, Jr J.H. (1963). Hierarchical grouping to optimize an objective function. Journal of the American Statistical Association, 58, 236-244.

Figure captions

Figure 1: Map of study area in the Celtic Sea. Red circles: deep-water hauls where the isotopic samples were collected. Blue circles: historical hauls of the FR-EVHOE survey used to select deep-sea species.

Figure 2: Mean $\delta^{15} \mathrm{~N}$ and $\delta^{13} \mathrm{C}$ values for all the studied taxa. Circles correspond to the results of a hierarchical cluster analysis. The correlation line between $\mathrm{C}$ and $\mathrm{N}$ values is shown. Species codes are given in Table 1.

Figure 3: Contributions (\%) of the potential prey groups to the diet of the 5 deep-sea species $(95,75$ and $50 \%$ credibility intervals).

Figure 4: Projection of $\mathrm{SEA}_{c}$ in the $\delta^{13} \mathrm{C} / \delta^{15} \mathrm{~N}$ plan for five deep-sea species. Ccae: Coelorinchus caelorhincus, Cmon: Chimaera monstrosa, Hdac: Helicolenus dactylopterus, Mlae: Malacocephalus laevis, Pble: Phycis blennoides. 


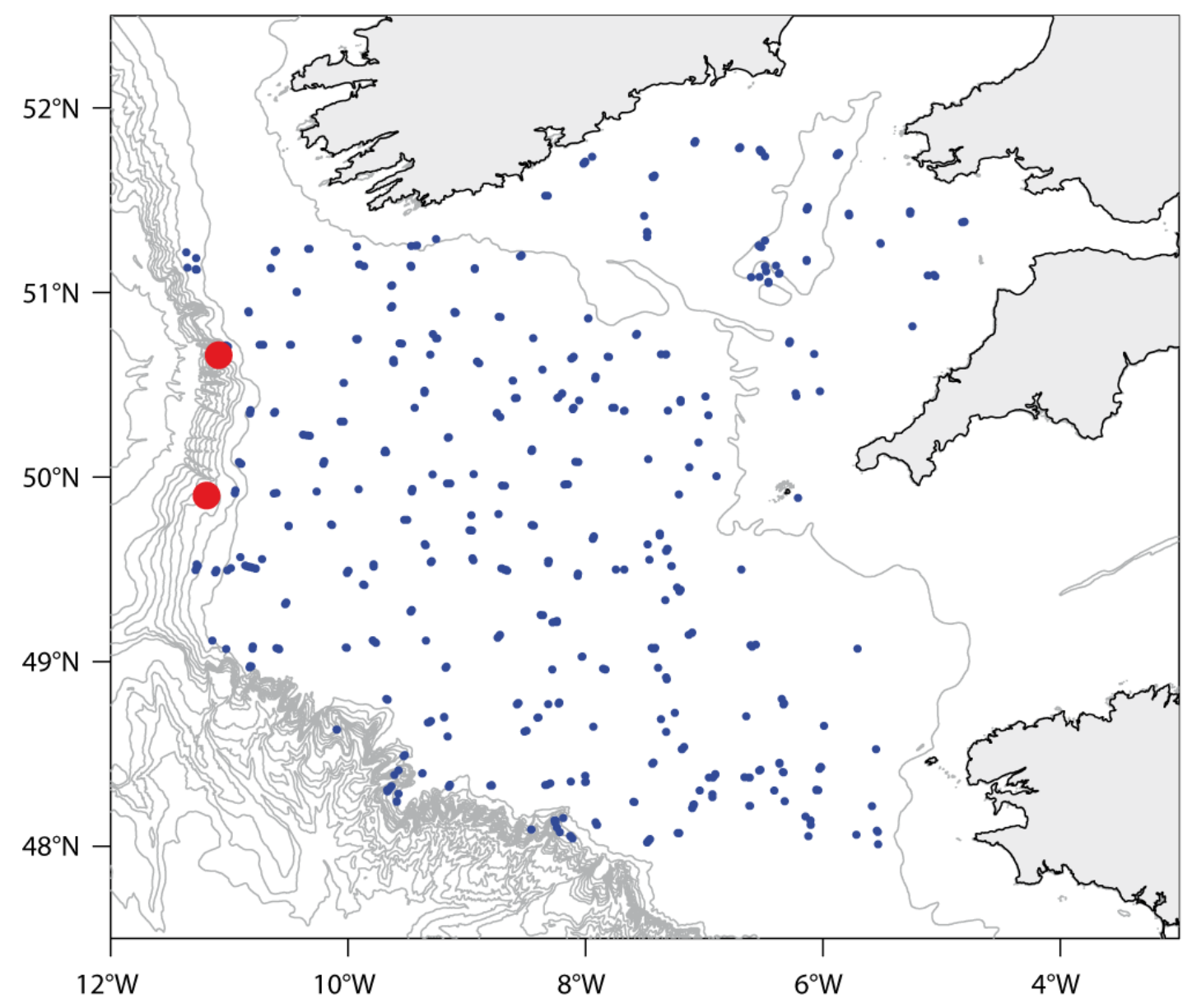

Fig. 1 


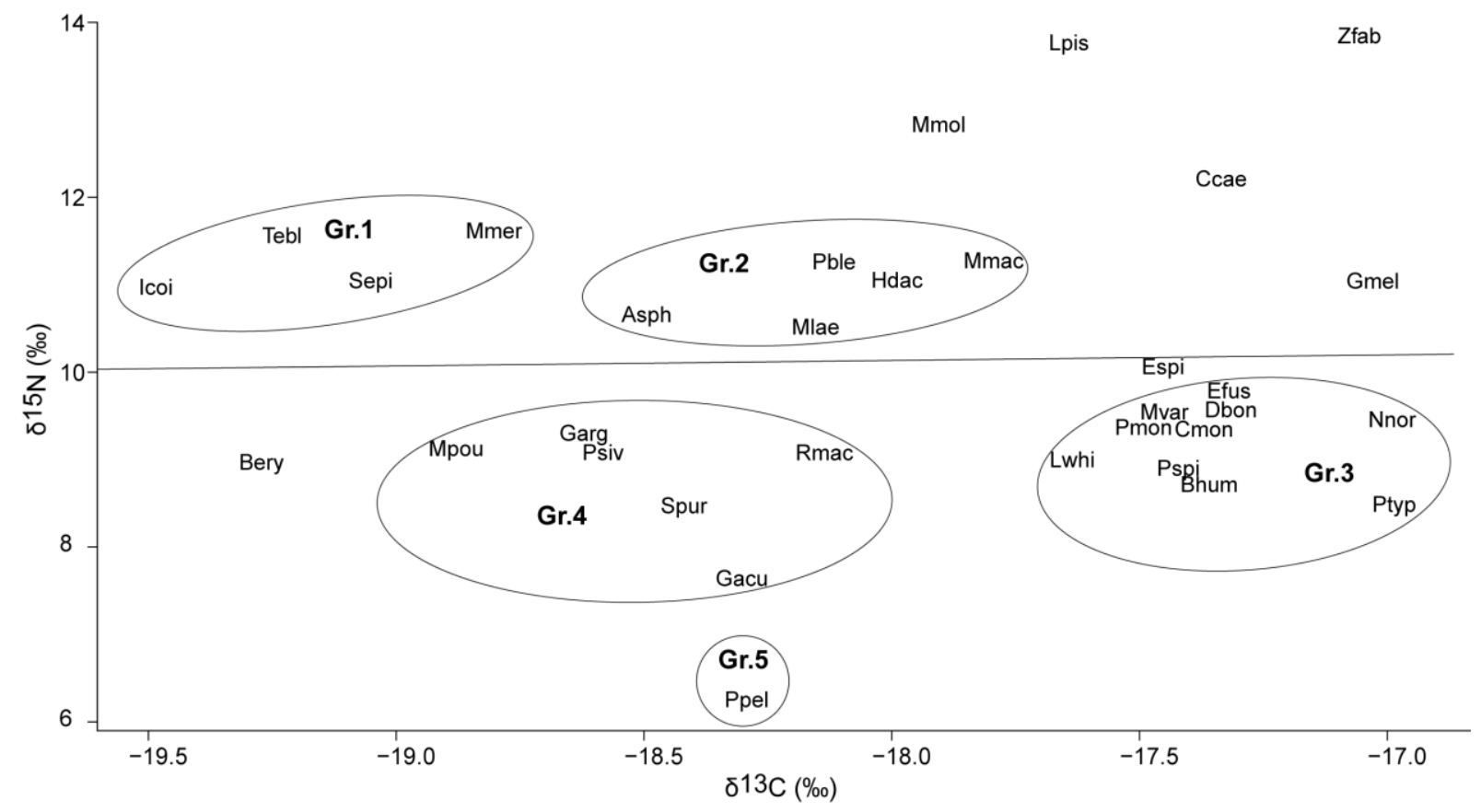

Fig. 2 

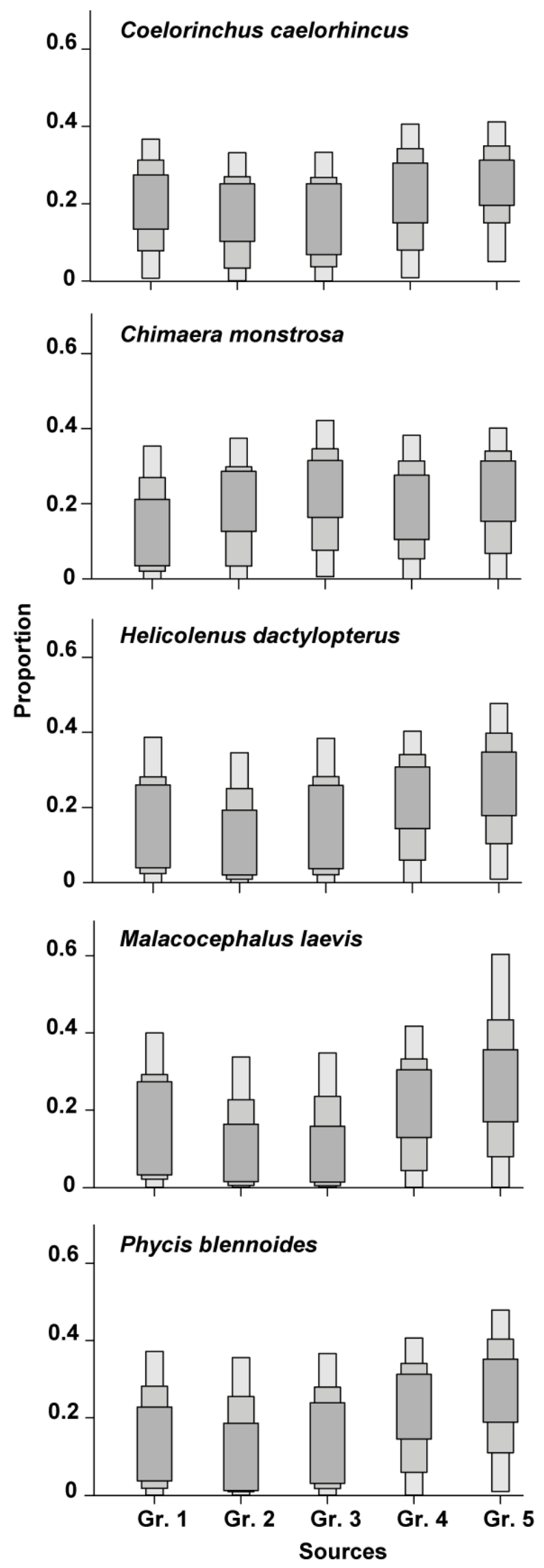

Fig. 3 


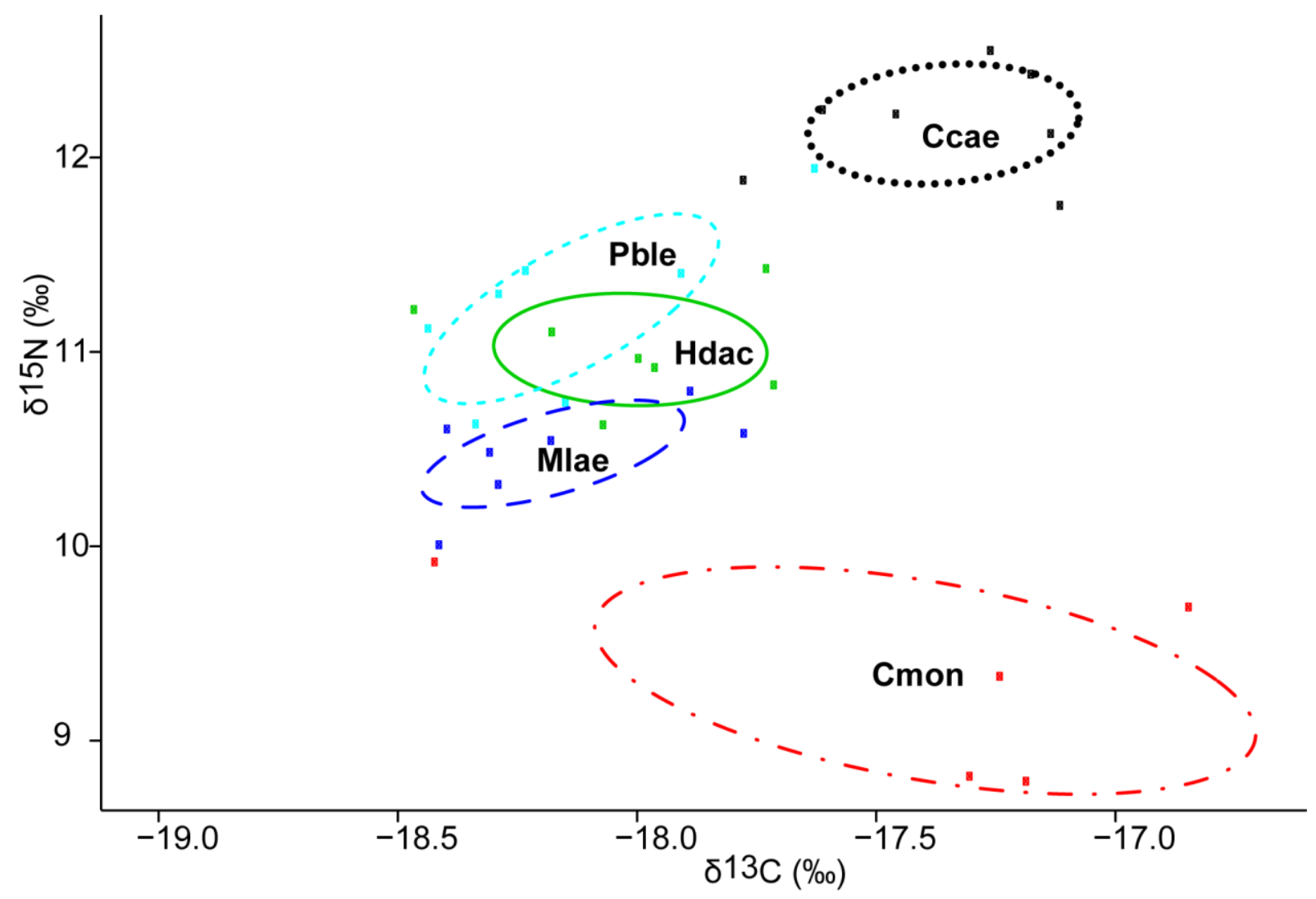

Fig. 4 
Table I: Names of all the studied species, species codes used in next Figures, number of individuals sampled $(\mathrm{n})$, mean $\delta^{13} \mathrm{C}$ and $\delta^{15} \mathrm{~N}( \pm \mathrm{SE}$ where appropriate).

\begin{tabular}{|c|c|c|c|c|}
\hline & Code & $\mathrm{n}$ & $\delta^{13} \mathrm{C}(\% 0) \pm \mathrm{SE}$ & $\delta^{15} \mathrm{~N}(\% 0) \pm \mathrm{SE}$ \\
\hline \multicolumn{5}{|l|}{ Fishes } \\
\hline Argentina sphyraena & Asph & 3 & $-18.5 \pm 0.3$ & $10.6 \pm 0.8$ \\
\hline Beryx spp & Bery & 2 & $-19.4-19.1$ & $8.6-9.2$ \\
\hline Chimaera monstrosa & Cmon & 5 & $-17.4 \pm 0.6$ & $9.3 \pm 0.5$ \\
\hline Coelorinchus caelorhincus & Ccae & 7 & $-17.4 \pm 0.3$ & $12.2 \pm 0.3$ \\
\hline Etmopterus spinax & Espi & 1 & -17.5 & 10.1 \\
\hline Gadiculus argenteus & Garg & 7 & $-18.6 \pm 0.7$ & $9.2 \pm 0.6$ \\
\hline Galeus melastomus & Gmel & 1 & -17.1 & 11.0 \\
\hline Helicolenus dactylopterus & Hdac & 7 & $-18.0 \pm 0,3$ & $11 \pm 0.3$ \\
\hline Lepidorhombus whiffiagonis & Lwhi & 7 & $-17.7 \pm 0.2$ & $8.9 \pm 0.4$ \\
\hline Lophius piscatorius & Lpis & 2 & $-18.3-17.1$ & $12.7-14.7$ \\
\hline Malacocephalus laevis & Mlae & 7 & $-18.2 \pm 0.3$ & $10.5 \pm 0.3$ \\
\hline Merluccius merluccius & Mmer & 8 & $-18.8 \pm 0.2$ & $11.6 \pm 0.8$ \\
\hline Microchirus variegatus & Mvar & 2 & $-17.6-17.3$ & $9.4-9.6$ \\
\hline Micromesistius poutassou & Mpou & 7 & $-18.9 \pm 0.6$ & $9.1 \pm 0.6$ \\
\hline Molva macrophthalma & Mmac & 5 & $-17.8 \pm 0.3$ & $11.2 \pm 0.6$ \\
\hline Molva molva & Mmol & 1 & -17.9 & 12.8 \\
\hline Phycis blennoides & Pble & 7 & $-18.1 \pm 0.3$ & $11.2 \pm 0.4$ \\
\hline Zeux faber & Zfab & 1 & -17.1 & 13.8 \\
\hline \multicolumn{5}{|l|}{ Crustaceans } \\
\hline Dichelopandalus bonnieri & Dbon & 3 & $-17.3 \pm 0.1$ & $9.6 \pm 0.4$ \\
\hline Nephrops norvegicus & Nnor & 7 & $-17.0 \pm 0.3$ & $9.4 \pm 0.4$ \\
\hline Pandalus montagui & Pmon & 7 & $-17.5 \pm 0.2$ & $9.4 \pm 0.2$ \\
\hline Pasiphae sivado & Psiv & 7 & $-18.6 \pm 0.2$ & $9.0 \pm 0.4$ \\
\hline Polycheles typhlops & Ptyp & 7 & $-17.0 \pm 0.2$ & $8.4 \pm 0.4$ \\
\hline Pontophilus spinosus & Pspi & 2 & $-17.9-17.0$ & $8.8-8.9$ \\
\hline \multicolumn{5}{|l|}{ Echinoderms } \\
\hline Gracilechinus acutus & Gacu & 7 & $-18.3 \pm 0.4$ & $7.6 \pm 0.4$ \\
\hline Spatangus purpureus & Spur & 5 & $-18.4 \pm 0.3$ & $8.4 \pm 0.3$ \\
\hline \multicolumn{5}{|l|}{ Molluscs } \\
\hline Buccinum humphreysianum & Bhum & 1 & -17.4 & 8.7 \\
\hline Euspira fusca & Efus & 1 & -17.4 & 9.7 \\
\hline Illex coindetii & Icoi & 7 & $-19.5 \pm 0.2$ & $10.9 \pm 0.6$ \\
\hline Pseudamussium peslutrae & Ppel & 5 & $-18.3 \pm 0.8$ & $6.2 \pm 0.6$ \\
\hline Rossia macrosoma & Rmac & 3 & $-18.1 \pm 0.2$ & $9.1 \pm 0.3$ \\
\hline Sepiola spp. & Sepi & 4 & $-19.1 \pm 0.4$ & $11.0 \pm 0.3$ \\
\hline Todaropsis eblanae & Tebl & 7 & $-19.2 \pm 0.2$ & $11.5 \pm 0.4$ \\
\hline
\end{tabular}

